\title{
Psicologia social dos estereótipos
}

\author{
Paula Bierrenbach de Castro Guerra ${ }^{1}$
}

Pereira, M. E. (2002). Psicologia social dos estereótipos. São Paulo, SP: EPU.

Marcos Emanoel Pereira leciona na Universidade Federal da Bahia as disciplinas psicologia social e psicologia social dos estereótipos, dedicando-se também ao estudo dos estereótipos étnicos. Seu livro, Psicologia social dos esterétipos, compreende sete capítulos e uma conclusão ao final.

A introdução corresponde ao primeiro capítulo e apresenta o enfoque de "quem são os outros", pela perspectiva da análise individual. O outro poderia ser qualquer um, inclusive o próprio observador em outra situação, e geralmente a análise do outro é feita por concepções errôneas, conferindo uma avaliação negativa. Várias anedotas étnicas são analisadas em termos sociológicos, delineando-se limites geográficos, sociais e morais de nações ou grupos, que refletem valores e normas. $\mathrm{O}$ autor mostra que há uma tendência sistemática na autovalorização e na valorização do próprio grupo, concomitante a uma desvalorização do outro, mas não há consenso de como ou por que isso ocorre.

O enfoque da instalação do estereótipo observa que pessoas, inicialmente, imaginam e definem o mundo e em seguida o observam. A interpretação estaria fundamentalmente associada à cultura, que determinaria de forma estereotipada a noção interna sobre o mundo externo. Assim, já haveria uma opinião formada, de acordo com os códigos da cultura, para se analisar o mundo antes mesmo de observá-lo. O mundo estaria ordenado por códigos, passados de geração a geração, favorecendo a estereotipia, que por função defenderia as tradições culturais e posições sociais.

O segundo capítulo apresenta um posicionamento etimológico e histórico dos termos estereótipo e estereotipia, centrando-se nas ciências sociais, que usam para referências às imagens generalizadas sobre grupos ou membros destes. Outra questão é a preocupação desta área em esclarecer os conteúdos dos estereótipos e suas influências à percepção social, julgamentos e comportamentos. Vários métodos de investigação dos estereótipos são descritos, porém afirma-se haver um predomínio da metodologia experimental. Questões conceituais sobre preconceito e discriminação, partindo-se da existência do estereótipo, e suas inter- relações são abordadas no terceiro capítulo. A idéia defendida é que tanto se alimentam discriminação e preconceito utilizando-se fatores sociais, afetivos, e cognitivos, quanto se diminuem com métodos, como a hipótese do contato e a redução da ignorância.

Desde a década de 90 , teorias sobre estereótipos têm considerado o individual ou o contextual, enfatizando ou não o conflito, delineando quatro perspectivas. A primeira observa a teoria individualista e o conflito, em geral teorias psicanalíticas, centradas em noções de repressão, projeção e catarse. Essa microanálise observa que crenças surgem com o tempo e devido a experiências repetidas. A segunda concepção avalia o contexto e não o conflito. São teorias socioculturais, que enfatizam a aprendizagem social, especialmente evolução e meios de transmissão dos estereótipos. A observação e repetição de comportamentos seria favorável à associação de um papel, um critério e por fim um diagnóstico social. Essa macroanálise enfoca que crenças são compartilhadas, sendo a sociedade o depósito da informação, além de admitir a importante influência da mídia, contribuinte para uma "indústria cultural". A teoria da identidade social corresponde à terceira concepção, reunindo a dimensão contextual e o conflito. Sugere que ao se perceber membro de um grupo, o indivíduo sente-se com as características daquele grupo, compartilhando percepções e comportamentos. A última abordagem refere-se à teoria da cognição social, que observa o individual e não o conflito. Essa visão considera estereótipos estruturas cognitivas, tem sido preponderante nos últimos vinte anos e estuda o processamento da informação, enfatizando os mediadores cognitivos. Esses processos favoreceriam a similaridade entre membros de um grupo. Seriam usados para racionalizar as próprias atitudes e dos demais e forneceriam prescrições, por definirem concepções e comportamentos em relação a uma situação. $\mathrm{O}$ autor descreve também mecanismos envolvidos na formação dos estereótipos, citando memória, atenção, codificação das informações, afetos, auto-imagem e processos automáticos controlados. Esses mecanismos seriam agentes na categorização do

${ }^{1}$ Endereço para correspondência:

Rua Buriti, 95 - Bairro Palmeiras - Campinas-SP - 13094-220

E-mail: guerraluis@uol.com.br 
outro, e por seguirem critérios diversos, tornam distinta a observação de cada um.

O penúltimo capítulo, de forma breve, aborda o quanto o estereótipo se aproxima da realidade, e sugere que a dificuldade para essa avaliação seja a ausência de critérios de analogia. Isso em razão de estereótipos não serem inatos e serem modificados com o tempo, pois as informações não são absorvidas, mas interpretadas, avaliadas, elaboradas, organizadas e armazenadas, em um processo influenciado pelas variáveis pessoais. O último capítulo retoma pontos já observados anteriormente, relacionando-os à evolução da criança, como a formação, o desenvolvimento e as mudanças dos estereótipos. As relações fundamentalmente moldariam e definiriam a maneira como se percebe e se avalia o outro. Todos os processos envolvidos, como cognitivos, afetivos, motivacionais, sociais e culturais, estariam correlacionados aos contatos e experiências com as pessoas e agentes de socialização. A família teria uma forte influência na formação dos estereótipos.

O modelo de influências de Bar-Tal para a formação e transmissão de estereótipos é apresentado. Este compreende background, grupos transmissores e variáveis pessoais mediadoras. $\mathrm{O}$ background sendo formado por relações entre grupos, condições políticas, sociais e econômicas, características e comportamentos dos outros. Os transmissores seriam compostos por mecanismos sociais, políticos, econômicos e educacionais, a influência dos familiares, os contatos diretos entre os grupos. As variáveis pessoais mediadoras são constituídas pelas atitudes e valores pessoais, personalidade, motivações e estilos cognitivos dos percebedores. Esse modelo tem sido eficiente para explicar a formação dos conteúdos específicos dos estereótipos, mas não para predizê-los efetivamente.

A argumentação conclusiva aborda a multicausalidade do fenômeno estereótipo, admitindo-se a ação conjunta dos fatores físicos, biológicos, individuais, grupais e contextuais envolvidos no processo de estereotipização. Acrescenta que a investigação dos estereótipos, embora tenha avançado, nas últimas três décadas, ainda é rudimentar. E sugere que, pela falta de unificação de idéias, proceda-se a identificação, circunscrição e o estabelecimento de limites explicativos para os fatores envolvidos. A bibliografia de sustentação dos capítulos é ampla, o que possibilita a continuidade do estudo.

Recebido em 15/10/2002 Aceito em 10/12/2002

Sobre a autora:

Paula Bierrenbach de Castro Guerra é psicóloga, graduada pela PUC-Campinas, mestranda em Psicologia na Universidade São Francisco. 